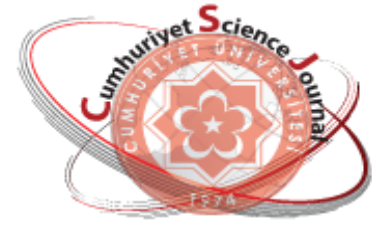

e-ISSN: $2587-246 X$

ISSN: 2587-2680

\section{Cumanoriyet Selence Journal}

est

Cumhuriyet Sci. J., Vol.38-4, Supplement (2017) 39-51

\title{
Structural, electrical, thermal, mechanical properties and micro-hardness in Sn-based Sn-Pb-Al ternary alloys
}

\author{
Canan ALPER BILLUR ${ }^{1 *}$, Mehmet ARI ${ }^{2}$, Tuncay KARAASLAN ${ }^{2}$, Buket SAATCI ${ }^{2}$ \\ ${ }^{1}$ Cumhuriyet University, Vocational School of Sivas, 58140 Sivas / TURKEY \\ ${ }^{2}$ Erciyes University, Department of Physics, 38039 Kayseri / TURKEY
}

Received: 02.10.2017; Accepted: 24.10.2017

http://dx.doi.org/10.17776/csj.341093

\begin{abstract}
The structural, electrical, thermal, mechanical properties and micro-hardness of five different samples of Sn-Pb-Al ternary alloys (Sn-[x] wt. \% Pb-10 wt. \% Al) (x=40, 30, 20 and 10) with constant $\mathrm{Al}$ concentrations, and the eutectic $\mathrm{Sn}-\mathrm{Pb}-\mathrm{Al}\left(\mathrm{Sn}_{61.82} \mathrm{~Pb}_{38.10} \mathrm{Al}_{0.08}\right)$ ternary alloy were investigated. The electrical conductivity of the samples, depending on temperature, was measured using the four-point probe technique (4PPT). The temperature dependence of the thermal conductivities of the samples was shown using the Wiedemann-Franz (W-F) law with the data obtained from electrical measurements. Scanning Electron Microscope (SEM), X-ray diffraction (XRD), and Energy Dispersive X-ray Analysis (EDX) measurements were carried out to reveal the surface morphology, crystal structure, cell parameters, grain sizes, and chemical compositions. Tensile tests were carried out to determine the ultimate tensile strengths depending on the particle size of each component in the alloys. The results of the micro-hardness tests were found using a Vickers test machine for each component of the alloys.
\end{abstract}

Keywords: Electrical and mechanical properties, Micro-hardness, Crystal structure

\section{Sn Temelli Sn-Pb-AI Üçlü Alaşımında Yapısal, Elektriksel, Termal, Mekaniksel Özellikler ve Mikrosertlik}

Özet: Ötektik Sn-Pb-Al $\left(\mathrm{Sn}_{61.82} \mathrm{~Pb}_{38.10} \mathrm{Al}_{0.08}\right)$ üçlü alaşımı ve sabit $\mathrm{Al}$ konsantrasyonunda $\mathrm{Sn}-\mathrm{Pb}-\mathrm{Al}$ üçlü alaşımının (Sn-[x] wt. \% Pb-10 wt. \% Al) (x=40, 30, 20 and 10) beş farklı örneğinin yapısal, elektriksel, termal, mekaniksel özelliği ve mikrosertliği araştırıldı. Örneklerin sıcaklığa bağlı olarak elektriksel iletkenliği dört nokta elektriksel iletkenlik tekniği kullanılarak ölçüldü. Örneklerin sıcaklığa bağlı olarak termal iletkenliği elektriksel ölçümlerden elde edilen datalarla birlikte Wiedemann-Franz (W-F) yasasıyla gösterildi. Taramalı elektron mikroskobu(SEM), X 1şınları difraktometresi(XRD), EDX ölçümleri, yüzey morfolojisini açığa çıkartmak, kristal yapı, hücre parametreleri, tane boyutları ve kimyasal bileşimini belirlemek için gerçekleştirildi. Çekme testleri alaşımdaki her bir bileşimin tane boyutlarına bağlı olarak en büyük gerilme mukavemetini belirlemek için gerçekleştirildi. Alaşımın herbir bileşimi için mikrosertlik sonuçları Vickers test cihazı kullanılarak bulundu.

Anahtar Kelimeler: Elektriksel ve mekaniksel özellikler, Mikrosertlik, Kristal yapı 


\section{INTRODUCTION}

Up to the present day, the structure, hardness, mechanical properties, friction coefficient, tribological properties, and miscibility gap of Sn$\mathrm{Pb}$-Al ternary alloy have been studied by many researchers using experimental or theoretical approaches [1-4]. However, in some of their studies, the ratio of Sn seemed to be decreased with an increasing proportion of the ratio of $\mathrm{Pb}$. [2-3]. We have studied the structural, electrical, thermal, mechanical properties and micro-hardness of Snbased $\mathrm{Sn}-\mathrm{Pb}-\mathrm{Al}$ ternary alloys (Sn-[x] wt. \% Pb-10 wt. $\% \mathrm{Al})(\mathrm{x}=40,30,20$ and 10 with constant $\mathrm{Al}$ concentration), and those of Sn-based eutectic Sn$\mathrm{Pb}-\mathrm{Al}\left(\mathrm{Sn}_{61.82} \mathrm{~Pb}_{38.10} \mathrm{Al}_{0.08}\right)$ ternary alloy, increasing the ratio of Sn depending on decreasing the ratio of $\mathrm{Pb}$ with constant $\mathrm{Al}$, excluding eutectic composition. However, in the above study, the selected composition ratios of $\mathrm{Sn}-\mathrm{Pb}-\mathrm{Al}$ ternary alloy had never been investigated until we carried out our investigation into the composition ratios of $\mathrm{Sn}-\mathrm{Pb}-\mathrm{Al}$ ternary alloy.

The crystal symmetry and cell parameters of the samples were determined from the XRD patterns. The microstructures of the ternary alloy were then analysed using SEM micrographs, on one side, the $\mathrm{Al}, \mathrm{Pb}$, and $\mathrm{Sn}$ compositions of the samples were determined using the EDX technique.
The temperature dependence of the electrical resistivity of the Sn based Sn-Pb-Al ternary alloy system was revealed using a standard DC 4PPT. In addition, the temperature coefficients of resistivity of the samples were calculated using the data from electrical conductivity measurements. The thermal conductivities of the samples were calculated using the Wiedemann-Franz (W-F) law with the data obtained from the electrical measurements. The correlation between the thermal conductivity and the electrical conductivity of all metals was given using the Wiedemann-Franz law, which is based on heat and electrical transport phenomena, as,

$$
\frac{\kappa}{\sigma}=L T
$$

where, $L$ is the constant of proportionality, which is called the Lorenz number. The value of $L$ is $2.45 \times 10^{-8} \mathrm{~W} \Omega / \mathrm{K}^{2}[5]$. In addition, although, the Wiedemann-Franz law was obtained for pure metals, this law has also been used in metal based binary and ternary alloys in many research studies [6-9]. The micro-hardness was measured using the Vickers test. Tensile tests were carried out to discover the mechanical properties.
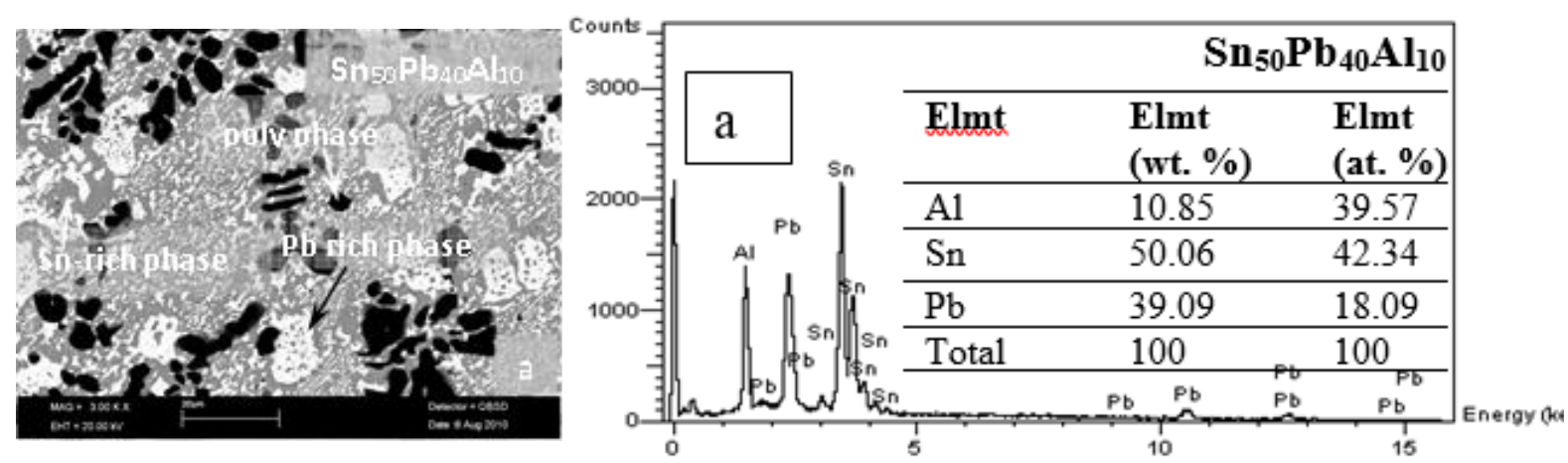

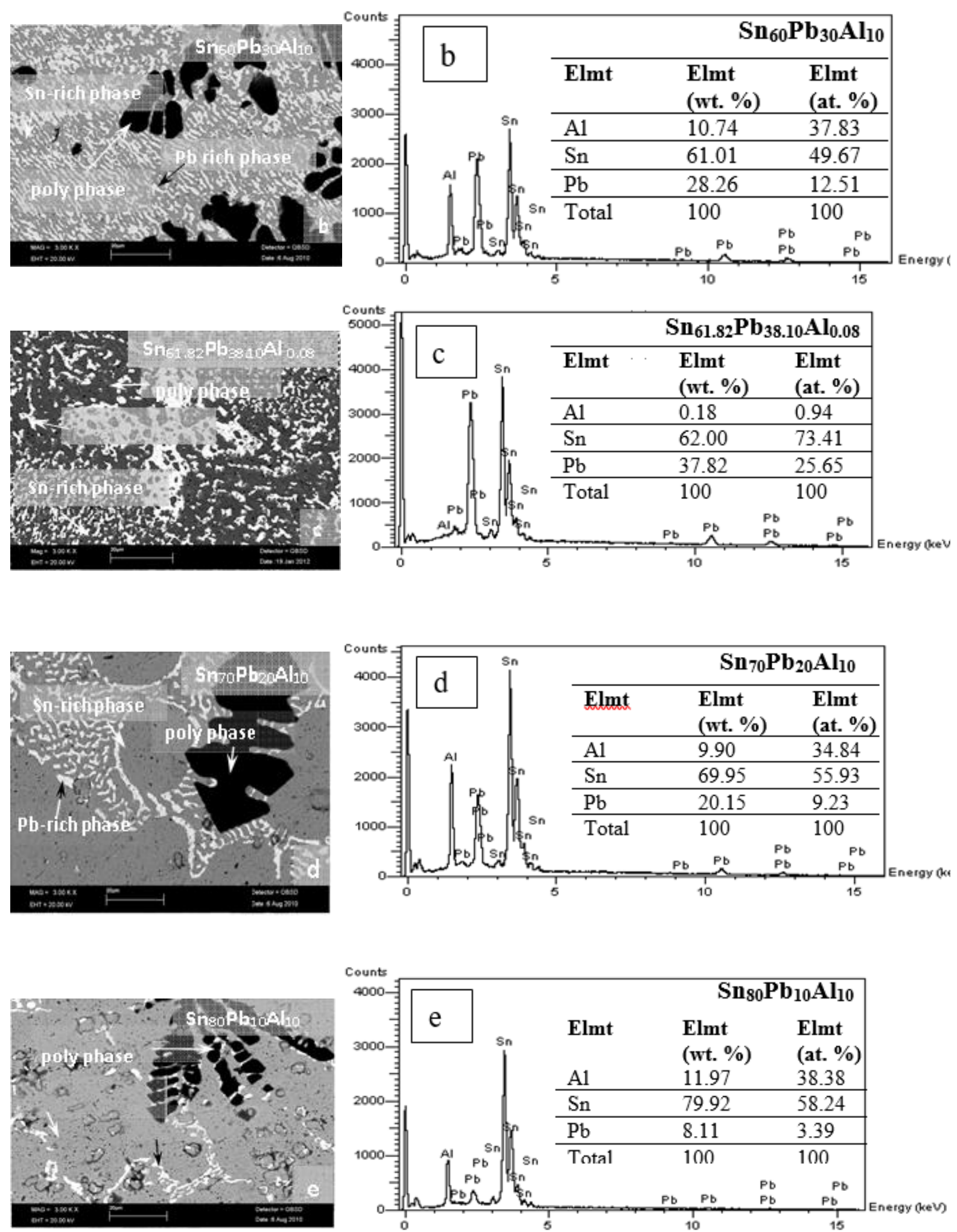

Figure 1 (left side). The SEM images for the $\mathrm{Sn}$ rich part of $\mathrm{Sn}-\mathrm{Pb}-\mathrm{Al}$ alloy system, grey phase (Sn-rich phase), white phase ( $\mathrm{Pb}$-rich phase), poly phase ( $\mathrm{Sn}-\mathrm{Pb}$ - $\mathrm{Al}$ phase). (right side) The chemical compositions analysis of the $\mathrm{Sn}-\mathrm{Pb}$ - $\mathrm{Al}$ alloy system for the Sn rich part by using EDX. 


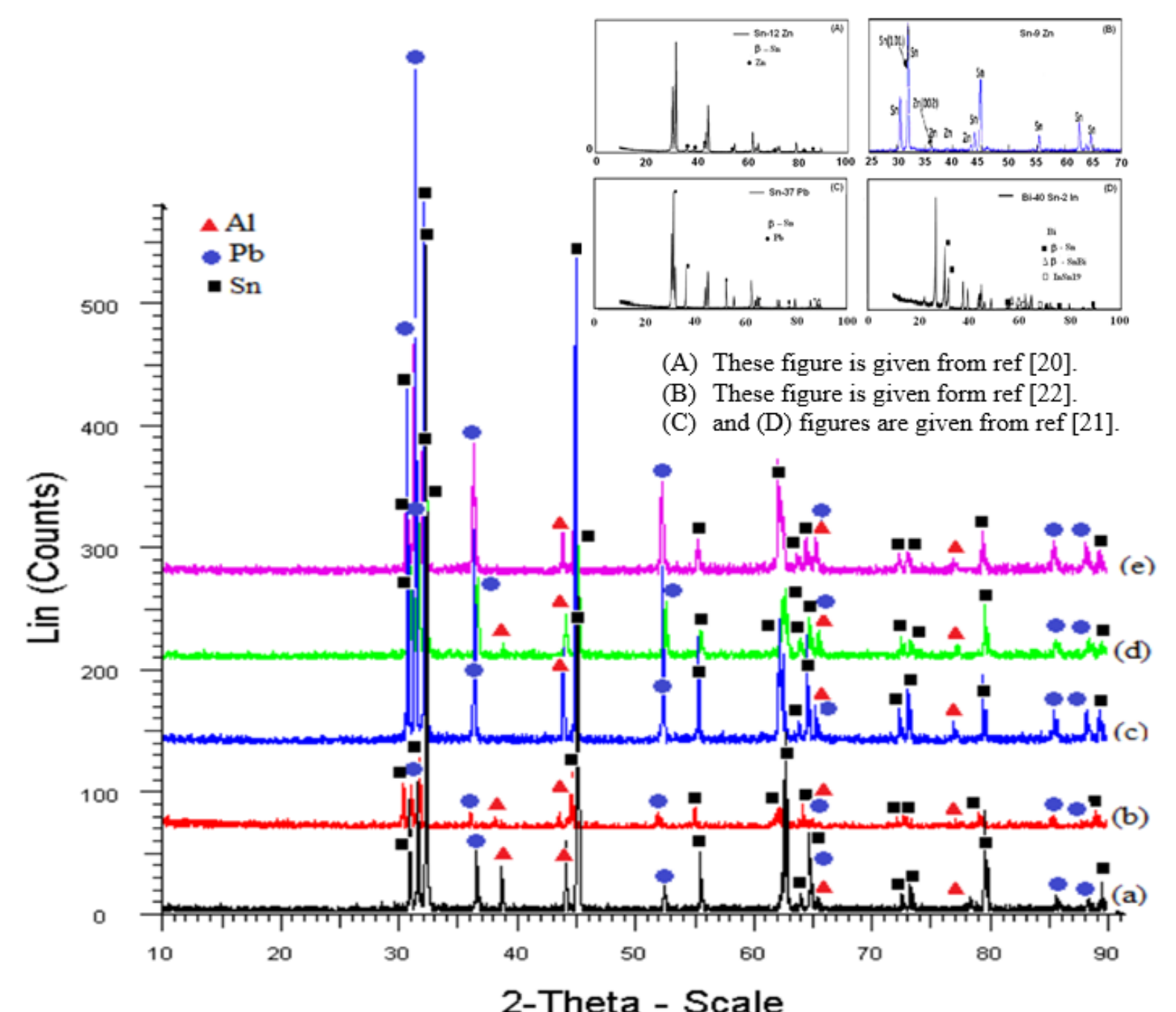

Figure 2. The measured XRD patterns of $\mathrm{Sn}-\mathrm{Pb}-\mathrm{Al}$ ternary alloy system after the solidification reactions for constant $\mathrm{Al}$. (a) Sn-10wt. \% Pb -10 wt. \% Al, (b) Sn-20wt. \% Pb -10 wt. \% Al, (c) Sn-38.1 wt. \% Pb -0.08 wt \%Al (d) Sn-30wt. \% Pb -10 wt. $\% \mathrm{Al},$. (e) Sn-40wt. \% Pb -10 wt. \% Al.

\section{METHOD AND MATERIALS}

\subsection{Sample Preparation}

The details of the apparatus used for the preparation of the Sn-based $\mathrm{Sn}-\mathrm{Pb}$-Al ternary alloy samples and eutectic $\mathrm{Sn}_{61.82} \mathrm{~Pb}_{38.10} \mathrm{Al}_{0.08}$ sample are given in references [6, 7,10-13]. Sufficient amounts of metallic materials was melted in a vacuum furnace to produce an ingot approximately $2 \mathrm{~cm}$ in length and $3 \mathrm{~cm}$ in diameter using $99 \%$ pure $\mathrm{Sn}, \mathrm{Pb}$ and $\mathrm{Al}$. First of all, a sufficient amount of pure materials was chemically cleaned, dried, weighted, and then dissolved in a vacuum furnace. Later, after being stirred frequently, the molten metal was poured into a graphite crucible $(30 \mathrm{~mm}$ diameter) held in a specially constructed casting furnace. Finally, solidification of the alloy was carried out directionally from bottom to top so that the crucible was completely filled and could be taken out afterwards.

\subsection{Structural Property Measurements}

The obtained samples were ground and polished using standard techniques and the SEM and EDX measurements were then carried out. The microstructures of the samples were characterized using an LEO 440 SEM equipped with an EDX spectrometer as well as a computer-controlled image analyser. After each electrical measurement, the chemical compositions of the samples were 
determined using the EDX spectrometer with a possible error of up to $1 \%$. The crystal structure and lattice parameters were determined using a computer-interfaced Bruker AXS D8 advanced diffractometer, operated in a Bragg-Brentano geometry $(\mathrm{CuK} \alpha$, graphite monochromator, $40 \mathrm{kV}$ and $40 \mathrm{~mA}$ ) over an angular range of $10^{\circ} \leq 2 \theta \leq 90^{\circ}$

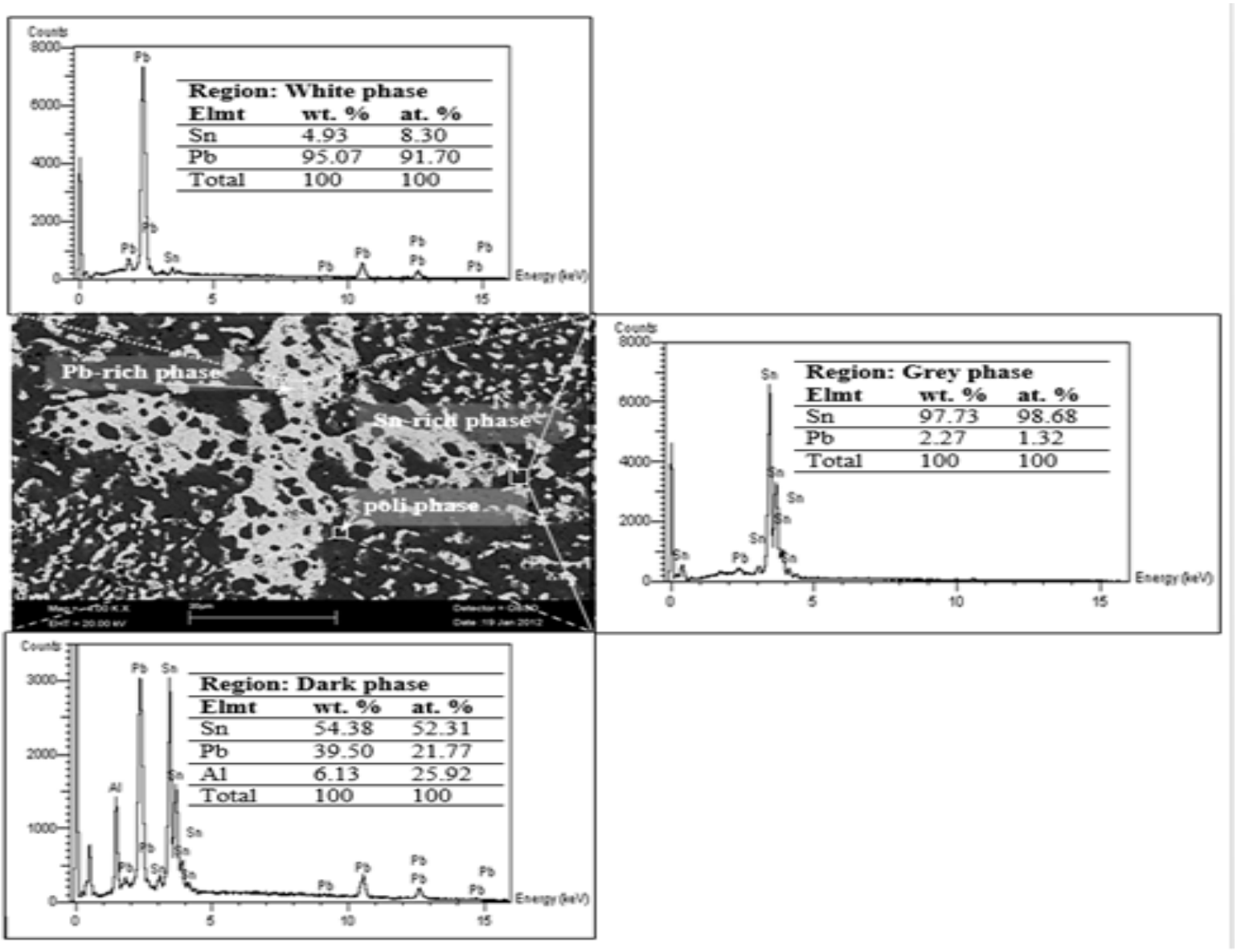

Figure 3. The quantitative chemical composition analysis of the Sn-Pb-Al alloy system by using SEM, EDX, grey phase (Snrich phase), poly phase (Al phase) and white phase (Pb-rich phase) for the $\mathrm{Sn}-38.1 \mathrm{wt} \% \mathrm{~Pb}-0.08 \mathrm{wt}$. \% Al.

which was used to record the XRD data of the samples of $\mathrm{Sn}-\mathrm{Pb}-\mathrm{Al}$ ternary alloys and the eutectic $\mathrm{Sn}_{61.82} \mathrm{~Pb}_{38.10} \mathrm{Al}_{0.08}$ sample. The diffractometer had a divergence of $1 \mathrm{~mm}$ and a receiving slit of $0.1 \mathrm{~mm}$ located on it. The diffraction patterns were scanned in $0.002^{\circ}(2 \theta)$ steps and the diffracted beams were counted using a $\mathrm{NaI}(\mathrm{Tl})$ scintillation detector.

To obtain the SEM images, the sample was cut transversely into $\sim 2-4 \mathrm{~mm}$ length sections. The transverse and longitudinal sections of the sample were examined for porosity, cracks, and casting defects to make sure that these would not introduce any errors into the measurements. They were then ground using 180-2400 grit $\mathrm{SiC}$ paper, and polished before the X-ray measurements were carried out. The XRD patterns were thus measured quickly and easily, and then compared with the reference data using DiffracPlus EVA and WinIndex software. The indexing of the XRD patterns of the $\mathrm{Al}, \mathrm{Sn}$, and $\mathrm{Pb}$ samples was carried out using the DICVOL 91 computer program.

The size of the grains in the samples, $t$, was calculated using the Scherrer Formula given below $[13,14]$, applying the DiffracPlus EVA computer program:

$$
t=\frac{0.9 \lambda}{\mathrm{B} \cos \theta}
$$


Where $\mathrm{B}$ is the half-width of the peak with maximum intensities of (200), (101), (211), and (220), $\theta$ is the Bragg angle, and $\lambda$ is the wavelength of the light used $(\lambda=1.54056 \stackrel{0}{A}$,
$\mathrm{CuK} \alpha$ in the present study). The TOPAS 2 program was also used to calculate the average grain size parameter LVol-(IB). The results are given in Table 1a.

Table 1a. Microstructural properties of the $\mathrm{Sn}-\mathrm{Pb}-\mathrm{Al}$ ternary alloy.

\begin{tabular}{|c|c|c|c|c|c|c|c|}
\hline $\begin{array}{l}\text { Compositions } \\
\text { of Alloys }\end{array}$ & Phases & $\begin{array}{l}\text { Crystal } \\
\text { System }\end{array}$ & paran & $\begin{array}{l}\text { it cell } \\
0 \\
\text { eters }(\stackrel{A}{)})\end{array}$ & $\begin{array}{c}\text { Volume } \\
0^{3} \\
(A)\end{array}$ & $\mathrm{c} / \mathrm{a}$ & $\begin{array}{l}\text { Grain Size } \\
\quad(\mathrm{nm})\end{array}$ \\
\hline $\mathrm{Sn}_{50} \mathrm{~Pb}_{40} \mathrm{Al}_{10}$ & $\begin{array}{l}(\mathrm{Sn}) \\
(\mathrm{Pb})\end{array}$ & $\begin{array}{l}\text { Body centered tetragonal } \\
\text { Cubic }\end{array}$ & $\begin{array}{l}a=5.8318 \\
a=4.9451\end{array}$ & $\mathrm{c}=3.1813$ & $\begin{array}{l}108.195 \\
120.929\end{array}$ & 0.5455 & 68.00 \\
\hline $\mathrm{Sn}_{60} \mathrm{~Pb}_{30} \mathrm{Al}_{10}$ & $\begin{array}{l}(\mathrm{Sn}) \\
(\mathrm{Pb})\end{array}$ & $\begin{array}{l}\text { Body centered tetragonal } \\
\text { Cubic }\end{array}$ & $\begin{array}{l}a=5.8333 \\
a=4.9460\end{array}$ & $\mathrm{c}=3.1822$ & $\begin{array}{l}108.282 \\
120.992\end{array}$ & 0.5455 & 63.00 \\
\hline $\mathrm{Sn}_{61.82} \mathrm{~Pb}_{38.10} \mathrm{Al}_{0.08}$ & $\begin{array}{l}(\mathrm{Sn}) \\
(\mathrm{Pb})\end{array}$ & $\begin{array}{l}\text { Body centered tetragonal } \\
\text { Cubic }\end{array}$ & $\begin{array}{l}a=5.8340 \\
a=4.9470\end{array}$ & $c=3.1780$ & $\begin{array}{l}108.165 \\
121.067\end{array}$ & 0.5447 & 61.33 \\
\hline $\mathrm{Sn}_{70} \mathrm{~Pb}_{20} \mathrm{Al}_{10}$ & $\begin{array}{l}(\mathrm{Sn}) \\
(\mathrm{Pb})\end{array}$ & $\begin{array}{l}\text { Body centered tetragonal } \\
\text { Cubic }\end{array}$ & $\begin{array}{l}a=5.8311 \\
a=4.9467\end{array}$ & $c=3.1825$ & $\begin{array}{l}108.211 \\
121.044\end{array}$ & 0.5457 & 54.39 \\
\hline $\mathrm{Sn}_{80} \mathrm{~Pb}_{10} \mathrm{Al}_{10}$ & $\begin{array}{l}(\mathrm{Sn}) \\
(\mathrm{Sn}) \\
(\mathrm{Pb}) \\
\end{array}$ & $\begin{array}{l}\text { Body centered tetragonal } \\
\text { Body centered tetragonal } \\
\text { Cubic }\end{array}$ & $\begin{array}{l}a=5.8315 \\
a=5.8368 \\
a=4.9451\end{array}$ & $\begin{array}{l}c=3.1814 \\
c=3.1915[20]\end{array}$ & $\begin{array}{l}108.187 \\
120.929 \\
\end{array}$ & $\begin{array}{l}0.5455 \\
0.5468[20]\end{array}$ & $\begin{array}{l}43.50 \\
45[25]\end{array}$ \\
\hline
\end{tabular}

\subsection{Electrical Measurements}

The electrical conductivities of the samples were determined using the DC 4PPT. By using the DC $4 \mathrm{PPT}$, the measurement errors due to probe resistance, the spreading resistance under each probe, and the contact resistances between the metal probes and the materials were eliminated [15].

The samples were cut transversely into $\sim 3-5 \mathrm{~mm}$ long sections and were then ground for the electrical conductivity measurements [6, 7, 10-12]. The measurements of the circular-shaped samples with a typical $3 \mathrm{~cm}$ diameter were conducted in the temperature range from room temperature to just below melting point. The measuring unit was interfaced with a PC for on-line data acquisition and processing. A Keithley 2400 SourceMeter was used to provide constant current and the potential drop was detected using a Keithley 2700 multimeter with a 7700 multiplexer switch card. Pt wires with a diameter of $0.5 \mathrm{~mm}$ were employed as current and potential probes.

Electrical conductivities were determined from the detected current and voltage drop using a standard conversion method [16-18]. The temperature of the sample was adjusted using a controllable
Nabertherm furnace. The temperature of the samples was also measured using a $0.5 \mathrm{~mm} \mathrm{~K}$ type thermocouple which was placed very close to the sample and detected using the Keithley 2700 multimeter.

The temperature coefficient of resistivities (TCR), $\alpha_{\rho}$, of the $\mathrm{Sn}-\mathrm{Pb}$-Al ternary alloys was estimated from the electrical resistivity results obtained in the temperature range $330-430 \mathrm{~K}$ using the following equation:

$$
\alpha_{\rho}=\left(\frac{1}{\rho_{1}}\right)\left(\frac{d \rho}{d T}\right)=\left(\frac{1}{\rho_{1}}\right)\left(\frac{\Delta \rho}{\Delta T}\right)
$$

Where $\alpha_{\rho}$ is the TCR in the temperature between $\Delta \mathrm{T}=\mathrm{T}_{2}-\mathrm{T}_{1}$ and $\Delta \rho=\rho_{2}-\rho_{1}$, and $\rho_{1}$ is the resistivity at $\mathrm{T}_{1}$ and $\rho_{2}$ is the resistivity at $\mathrm{T}_{2}$.

In addition, the thermal conductivity temperature coefficients (TCTC), $\alpha_{\kappa}$, of the Sn-Pb-Al ternary alloys were calculated from the electrical resistivity results obtained in the temperature range 300-430 $\mathrm{K}$ using the Wiedemann-Franz law and the following equation:

$$
\alpha_{\kappa}=\left(\frac{1}{\kappa_{1}}\right)\left(\frac{d \kappa}{d T}\right)=\left(\frac{1}{\kappa_{1}}\right)\left(\frac{\Delta \kappa}{\Delta T}\right)
$$


where is the TCTC in the temperature between $\Delta \mathrm{T}=\mathrm{T}_{2}-\mathrm{T}_{1}$ and $\Delta \kappa=\kappa_{2}-\kappa_{1}$, where $\kappa_{1}$ is the

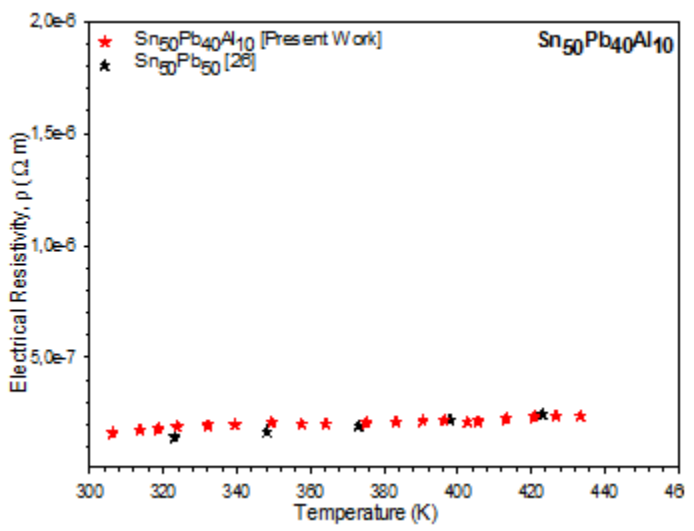

(a)

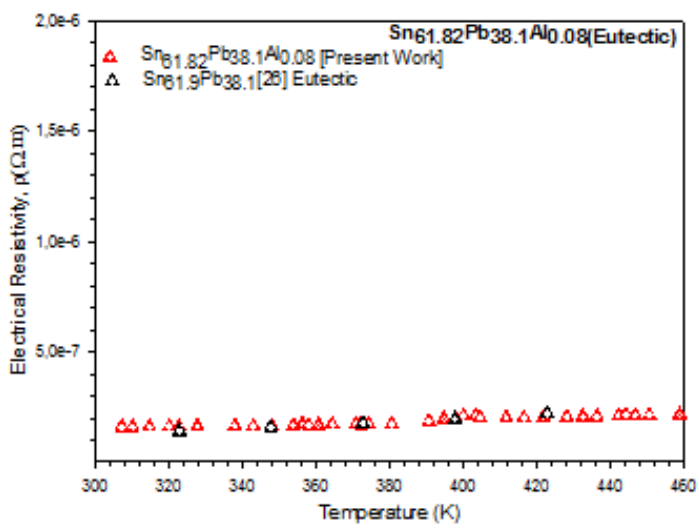

(c) thermal conductivity at $\mathrm{T}_{1}$ and $\kappa_{2}$ is the thermal conductivity at $\mathrm{T}_{2}$

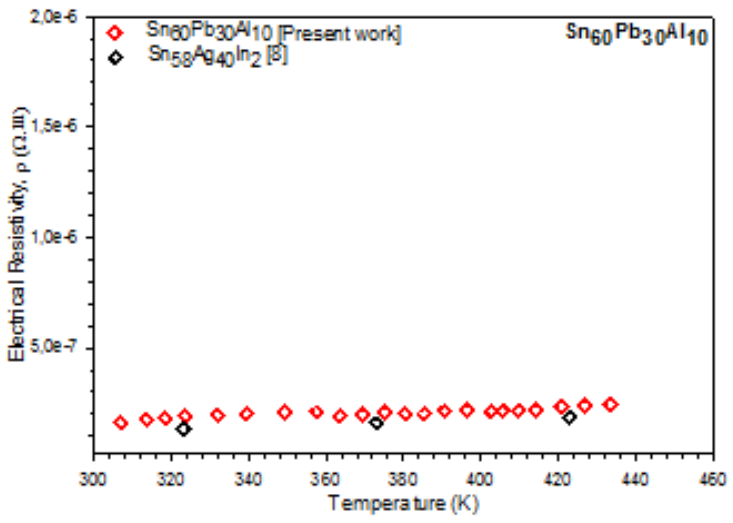

(b)

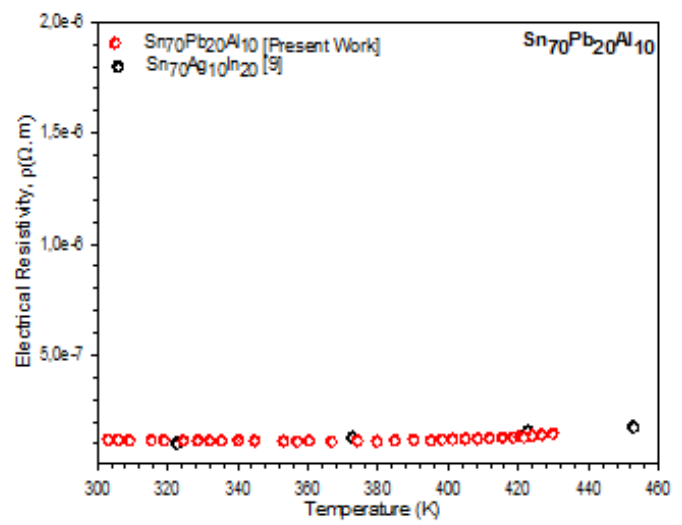

(d)

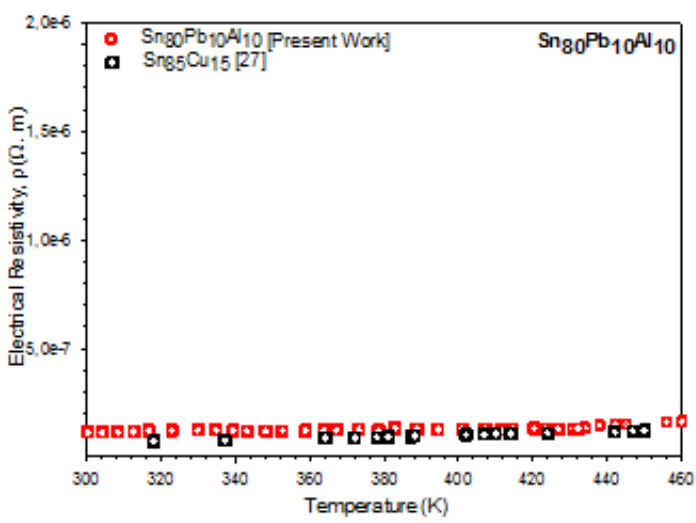

(e)

Figure 4. Electrical resistivity of the each components of $\mathrm{Sn}-\mathrm{Pb}-\mathrm{Al}$ alloy system versus temperature for constant aluminum concentration.

\subsection{Measurement of Micro-Hardness and} Mechanical Properties

The mechanical properties of solidified materials are usually decided using micro-hardness, tensile strength, and ductility tests, etc. One of the purposes of this present study was to obtain the relationships between composition $\left(\mathrm{C}_{\mathrm{o}}\right)$ and microhardness (HV) for the $\mathrm{Sn}-\mathrm{Pb}-\mathrm{Al}$ ternary alloy (Sn[x] wt. \% Pb-10 wt. \% Al) $(\mathrm{x}=40,30,20$ and 10) 
with constant $\mathrm{Al}$ concentrations, and for eutectic $\mathrm{Sn}-\mathrm{Pb}-\mathrm{Al}\left(\mathrm{Sn}_{61.82} \mathrm{~Pb}_{38.10} \mathrm{Al}_{0.08}\right)$. There are many methods for measuring the micro-hardness of materials. However, the most commonly used form of measuring micro-hardness is the Vickers hardness test. The micro-hardness tests were carried out on a STRUERS brand DURAMIN 5 model Vickers micro-hardness test machine with $10 \mathrm{~g}$ loading at room temperature.

Another aim of this study was to measure the ultimate tensile strength dependent on each component of the alloy, and the obtained results were compared, dependent on the grain size for (Al-[x] wt. \% Sn-10 wt. \% Pb) (x=40, 30, 20 and 10). In the present study, at least four samples in each composition were used to obtain more reliable results for their ultimate tensile strengths. The tensile tests were carried out on a SHIMADZU brand AG-X plus Series model Materials test machine at room temperature with a strain rate of $20 \mathrm{~mm} / \mathrm{min}$. To obtain the tensile test samples used in the experiments, $10 \mathrm{~mm}$ width and $60 \mathrm{~mm}$ length samples were produced.

\section{RESULTS AND DISCUSSION}

The surface morphology of the samples was observed from the SEM images. The best contrast for the SEM images was found between the phases in the matrix by using the backscatter detector. As seen from Fig.1(left side), the Sn-Pb-Al ternary alloy has a homogeneous polycrystalline structure and any impurities, such as porosity, crack, hole or structural defect, are not seen in the SEM images of the samples. Significant and similar characteristics were found in terms of the surfaces, morphologies and grain structure of the alloyed samples. The microstructure of the $\mathrm{Sn}-\mathrm{Pb}-\mathrm{Al}$ ternary alloy consists of the poly phase, Sn-rich phase, and $\mathrm{Pb}$-rich phase, as shown in Fig.1(left side). As shown in Fig.1(right side), the results of the EDX analysis depict a typical EDX pattern and account for the relative analysis of the samples. In the results of the EDX analysis, the $\mathrm{Al}, \mathrm{Pb}$ and $\mathrm{Sn}$ peaks were clearly seen and the composition shows similarities with those taken after electrical measurements. The measured XRD patterns of the
$\mathrm{Sn}$ - $\mathrm{Pb}$-Al ternary system after the solidification reactions for the Sn side are seen in Fig 2.

Fig.2. shows that the XRD spectra of the 40, 30, 20 and 10 wt. \% Sn doping Sn solid samples and $\mathrm{Sn}_{61.82} \mathrm{~Pb}_{38.10} \mathrm{Al}_{0.08}$ eutectic sample for constant aluminium concentration (except for the eutectic samples only) are very similar to the XRD patterns. The calculated unit cell parameter values of the molar volume type of the alloyed samples vary in the range of $\mathrm{a}=5.8311-5.8340 \AA, \mathrm{c}=3.1780-3.1825$ $\AA, \mathrm{Vol}=108.165-108.282\left(\AA^{3}\right), \mathrm{c} / \mathrm{a}=0.5447-0.5457$ for the Sn-rich phase, and $a=4.9451-4.9470 \AA$, Vol=120.929-121.067 $\left(\AA^{3}\right)$ for the Pb-rich phase, and are given in Table 1a. The unit cell parameter values and the crystal symmetry for pure $S n$ are given in pattern 4-673, while the PDF for $\mathrm{Pb}$ is given in pattern 4-686.

In addition, the pure $\beta$-Sn phase has body-centred tetragonal crystal structure symmetry. There are small deviations from the pure tin peaks. The structure of the $\mathrm{Sn}-\mathrm{Pb}-\mathrm{Al}$ ternary alloy remains unchanged. However, some small changes were observed in the obtained unit cell parameters which could be due to the precision level of the measurement system. Furthermore, the calculated c/a values of the samples vary in the range of 0.5447-0.5457. The XRD patterns of the Sn-Pb-Al ternary alloy system were compared with the other similar studies [19-21]. The obtained results in the present work are in good agreement with the results from Shalaby [19-20] and Billah et al. [21] and there are also given in Fig.2. For example, the lattice parameters of the $\mathrm{Sn}-37 \mathrm{~Pb}$ eutectic binary alloy were calculated as a $=5.8329 \AA, \mathrm{c}=3.1783 \AA$ and $\mathrm{c} / \mathrm{a}=0.5448$, and the lattice parameters of the $\mathrm{Bi}-40 \mathrm{Sn}-2$ in the ternary alloy was calculated as a $=5.8110 \AA, \mathrm{c}=3.1700 \AA$ and $\mathrm{c} / \mathrm{a}=0.5455$. The grain sizes of the alloy samples were determined from the XRD patterns using the DiffracPlus EVA and TOPAS 2 software programs [22, 23]. The results show that the average grain size of the samples increases with decreasing $\mathrm{Sn}$ and increasing $\mathrm{Pb}$ concentrations. The average grain size of the samples was calculated from the higher intensity peaks of the XRD pattern of (200), (101), (211), (220), and (112). The values of the average 
grain sizes in the present study were found in the range of 43.50-68.00 nm and are given in Table 1a. Our grain size results in $\mathrm{Sn}-10$ wt. $\mathrm{Pb}-10$ wt. \% $\mathrm{Al}$ are in good agreement with the results from Mishra et al. [24] for the $\mathrm{Sn}_{80} \mathrm{Ni}_{10} \mathrm{Sb}_{10}$ nano-alloy system. The results of our c/a values in the Sn-10 wt. Pb-10 wt. \% $\mathrm{Al}$ are also in good agreement with the results from Shalaby [19] for $\mathrm{Sn}_{88} Z_{n_{12}}$. The

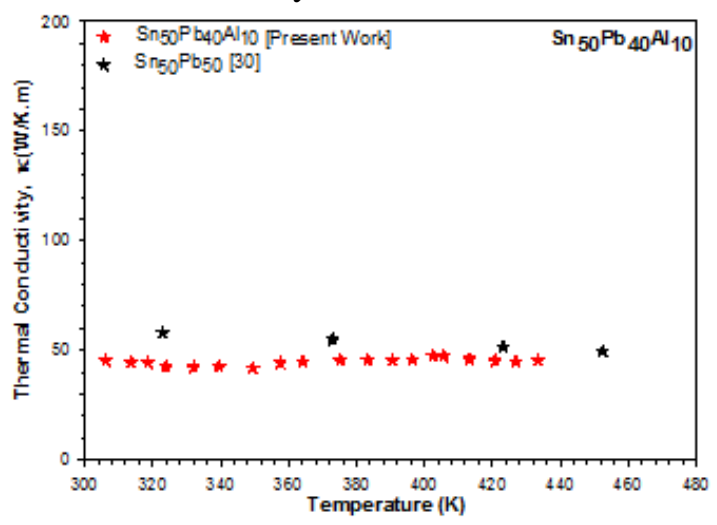

(a)

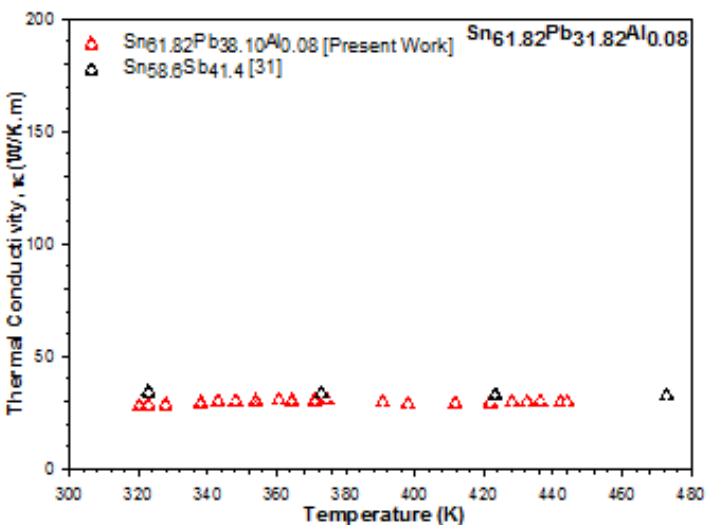

(c) quantitative chemical composition EDX analysis of various selected regions in the solid phase of the $\mathrm{Sn}_{61.82} \mathrm{~Pb}_{38.10} \mathrm{Al}_{0.08}$ sample was also conducted and the obtained results are given in Fig.3. As clearly seen from Fig.3,

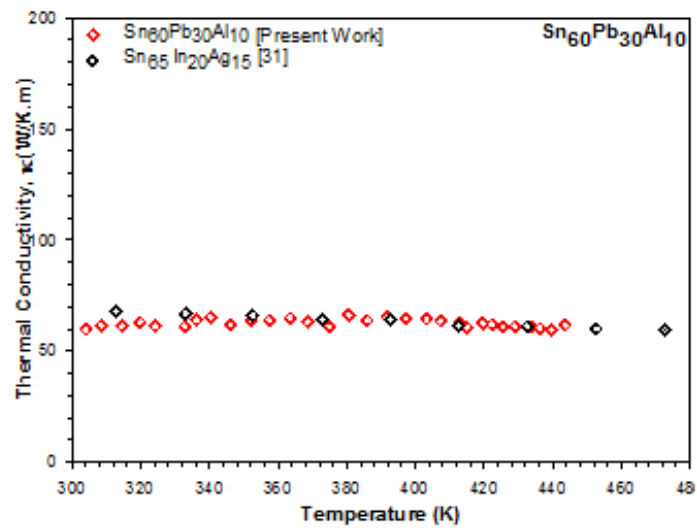

(b)

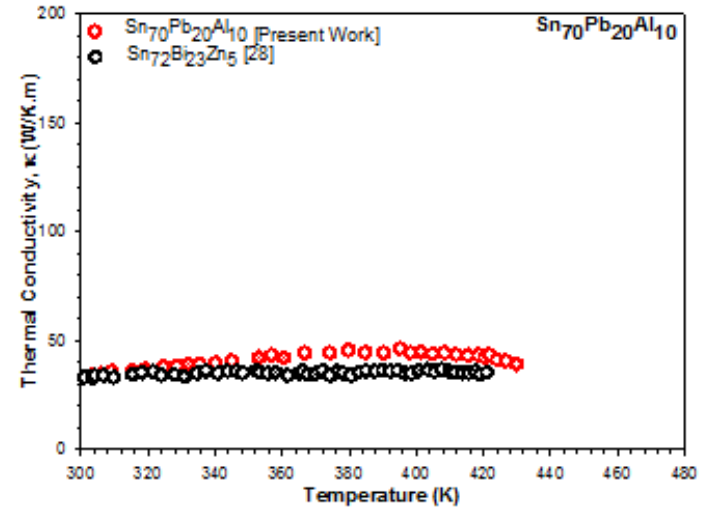

(d)

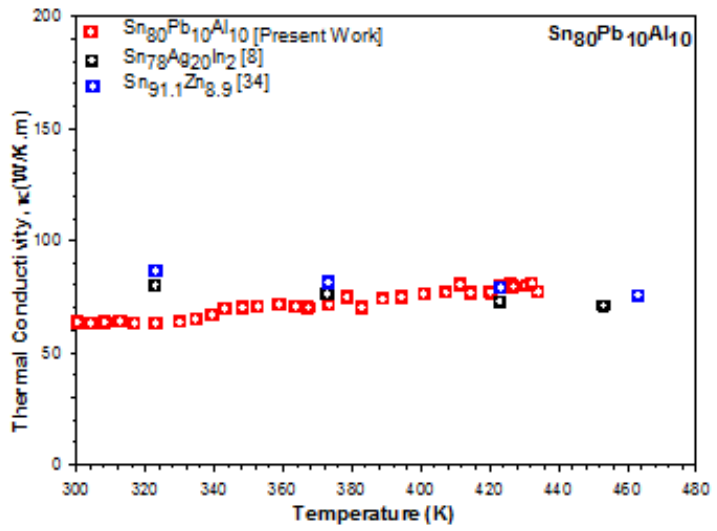

(e)

Figure 5. The variations of the thermal conductivity versus temperature for $\mathrm{Sn}-[\mathrm{x}]$ wt. \% Pb-10 wt. \% Al (x=40, 30, 20 and 10) and eutectic $\mathrm{Sn}-\mathrm{Pb}-\mathrm{Al}$ alloy system. 
the poly-phase, $\mathrm{Sn}$-rich and $\mathrm{Pb}$-rich phases are all present. The same phases were also observed for the other alloyed samples.

The temperature-dependent electrical resistivities of the samples, $\rho$, were obtained in the temperature range between $330 \mathrm{~K}$ and $430 \mathrm{~K}$ and are given in Table 1b. Additionally, the measured values of electrical resistivity versus temperature are plotted in Fig.4. The resistivity-temperature curves of all samples show similar characteristics. The calculated electrical resistivity values of the samples were in the range of $1.11 \times 10^{-7}-2.44 \times 10^{-7}$ $\Omega \mathrm{m}$. All of our experimental electrical results are consistent with the results of Ocak et al [8], Aksöz et al [9], and Çadırlı et al [25-27].

Table 1b. Electrical, and Thermal properties of the $\mathrm{Sn}-\mathrm{Pb}-\mathrm{Al}$ ternary alloy.

\begin{tabular}{|c|c|c|c|c|c|c|}
\hline \multirow[t]{2}{*}{ Compositions of Alloys } & \multicolumn{2}{|c|}{$\begin{array}{l}\text { Electrical resistivity } \rho \\
10-7(\Omega \mathrm{m})\end{array}$} & \multicolumn{2}{|c|}{$\begin{array}{l}\text { Thermal Conductivity } \kappa \\
(\mathrm{W} / \mathrm{Km})\end{array}$} & \multirow{2}{*}{ 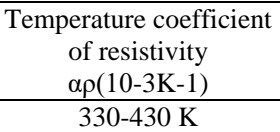 } & \multirow{2}{*}{ 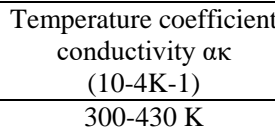 } \\
\hline & $\mathrm{T}=330 \mathrm{~K}$ & $\mathrm{~T}=430 \mathrm{~K}$ & $\mathrm{~T}=300 \mathrm{~K}$ & $\mathrm{~T}=430 \mathrm{~K}$ & & \\
\hline Sn50Pb40A110 & 1.97 & 2.39 & 45.30 & 45.48 & 2.14 & 0.30 \\
\hline Sn60Pb30A110 & 1.97 & 2.44 & 58.33 & 60.66 & 2.36 & 3.07 \\
\hline Sn61.82Pb38.10A10.08 & 1.67 & 2.11 & 59.72 & 61.14 & 2.65 & 1.83 \\
\hline $\mathrm{Sn} 70 \mathrm{~Pb} 20 \mathrm{~A} 110$ & 1.11 & 1.44 & 34.27 & 39.17 & 2.95 & 10.99 \\
\hline Sn80Pb10A110 & 1.26 & 1.33 & 63.53 & 80.04 & 0.56 & 19.90 \\
\hline
\end{tabular}

The obtained data from the present study agree well with the recommended values of electrical data for other Sn-rich studies [9, 25-28]. It can be seen that the electrical resistivity values to be accordance with the literature and show that metallic type resistivity behaviour, as expected. The TCRs of the samples were determined using data from the electrical resistivity measurements.

The temperature-dependent thermal conductivities of the samples, $\kappa$, were obtained in the temperature range between $300 \mathrm{~K}$ and $430 \mathrm{~K}$ and were given in Table 1b. While the measured values of thermal conductivity versus temperature are plotted in Fig.5. The obtained data from the present study agree well with the recommended values of thermal electrical data for other Sn-rich studies [29-33].

The thermal conductivity data shows little change with increasing temperature, which is an indication of metallic type conductivity behaviour, as expected. The TCTCs of the samples were determined using data from the electrical resistivity measurements using the Wiedemann-Franz law. The calculated thermal conductivity values of the samples were in the range of 34.27 - 80.04 W/K.m.
The variation of Sn content has a great impact on the grain size, ultimate tensile strength and hardness of the ternary alloy. The effect of Sn concentrations on ultimate tensile strength and grain size of the $\mathrm{Sn}-\mathrm{Pb}-\mathrm{Al}$ ternary alloy having constant Al concentrations is shown in Fig.6. The Sn addition to the alloy decreased the grain size. The values of the average grain sizes of the present study were found to be in the range of 43.50-68.00 $\mathrm{nm}$ and are given in Table $1 \mathrm{a}$.

The grain boundaries of the sample increased with the reduction of the grain size. Therefore, the toughness of alloy has increased. At the same time, due to the motion of dislocation in the small grain boundary being more difficult than at a large grain size, the stress concentration in front of the grain boundary is increased and has led to the strengthening of the alloy (Fig.6). 


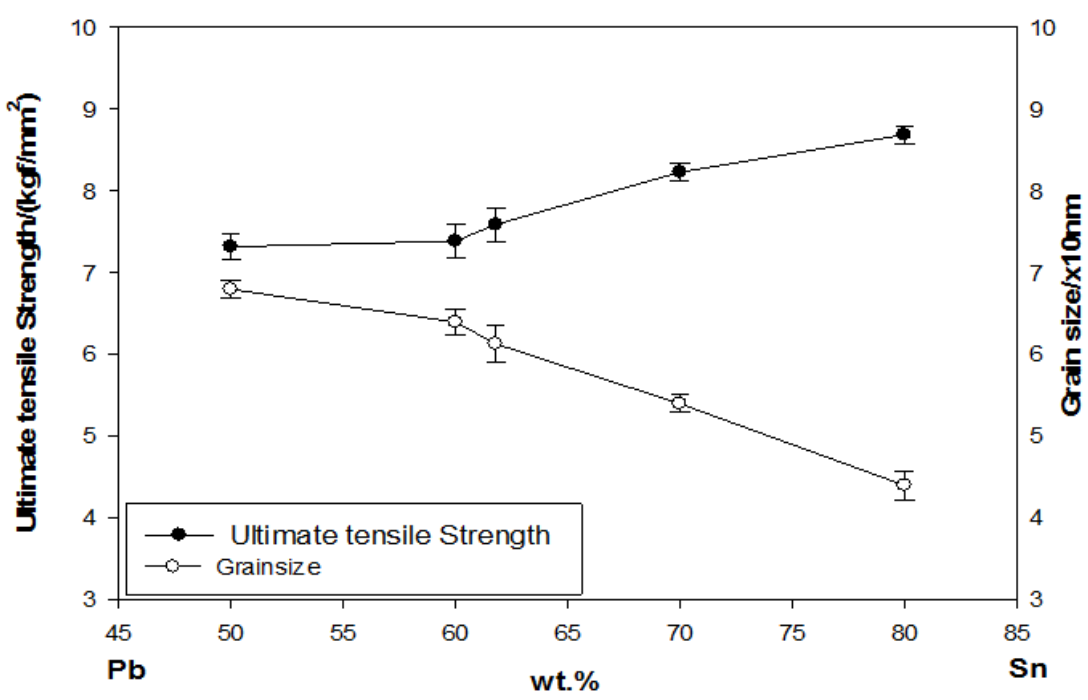

Figure 6. The variations of ultimate tensile strength and grain size versus concentration of the $\mathrm{Sn}-\mathrm{Pb}-\mathrm{Al}$ alloy system.

The effect of Sn concentrations on Vicker-Microhardness and grain size for $\mathrm{Sn}-\mathrm{Pb}-\mathrm{Al}$ ternary alloy having constant $\mathrm{Al}$ concentrations is shown in Fig.7. Tin is harder than lead. The hardness of the alloy increased like the ultimate tensile strength when tin concentrations were increased and lead decreased in the alloy (Fig.7). The calculated micro-hardness values of the samples were in the range of $18.55-24.4 \mathrm{HV}$. Because grain boundaries of the sample increased with the reduction of the grain size, the strength and hardness of the alloy also increased. Therefore, it is seen that the microhardness increased depending on the reduction of grain size for the $\mathrm{Sn}-\mathrm{Pb}$-Al ternary alloy (Fig.7).

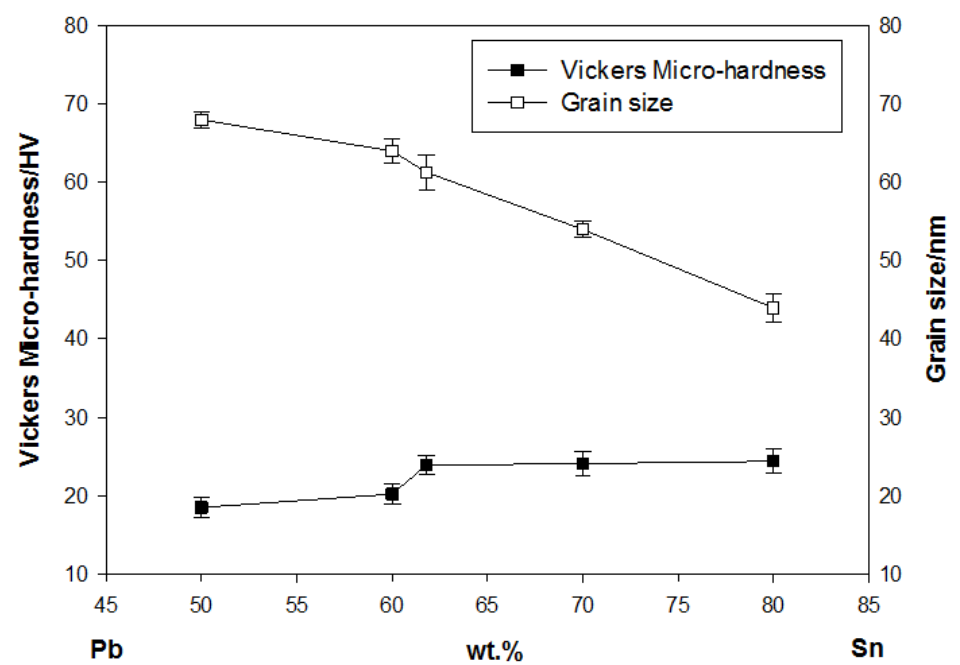

Figure 7. The micro-hardness and grain size versus concentration for $\mathrm{Sn}-[\mathrm{x}]$ wt. \% Al (x=40, 30, 20 and 10) and eutectic $\mathrm{Sn}-\mathrm{Pb}-$ Al alloy system.

\section{CONCLUSION}

The crystal structural, cell parameters, grain size, the electrical, mechanical properties and microhardness of five different samples of $\mathrm{Sn}-\mathrm{Pb}-\mathrm{Al}$ ternary alloys (Sn-[x] wt. \% Pb-10 wt. \% Al) $(\mathrm{x}=40,30,20$ and 10$)$ with constant $\mathrm{Al}$ concentrations, and for eutectic Sn-Pb-Al $\left(\mathrm{Sn}_{61.82} \mathrm{~Pb}_{38.10} \mathrm{Al}_{0.08}\right) \quad$ ternary alloy were investigated. The results are summarized as follows: 
1. The calculated unit cell parameter values of the molar volume type of the alloyed samples vary in the range of $a=5.8311$ $5.8340 \AA$,

$\mathrm{c}=\quad 3.1780-3.1825 \AA, \quad \mathrm{Vol}=108.165-$ 108.282( $\left.\AA^{3}\right), \mathrm{c} / \mathrm{a}=0.5447-0.5457$ for $\mathrm{Sn}$-rich phase, $\quad \mathrm{a}=4.9451-4.9470 \AA$, $\mathrm{Vol}=120.929$ $121.067\left(\AA^{3}\right)$ for Pb-rich phase.

2. The values of the average grain sizes of present work were found in the range of 43.50-68.00nm.

3. The calculated electrical resistivity values of the samples were in the range of $1.11 \times 10^{-7}$ $2.44 \times 10^{-7} \Omega \mathrm{m}$.

4. The calculated thermal conductivities values of the samples were in the range of 34.27$80.04 \mathrm{~W} / \mathrm{Km}$

5. The calculated micro-hardness values of the samples were in the range of $18.55-24.4 \mathrm{HV}$.

6. The ultimate tensile strength values of the samples were in the range of 7.32 $8.69 \mathrm{kgf} / \mathrm{mm}^{2}$.

\section{REFERENCES}

[1]. Guang-ming X., Bao-mian L., Jian-zhong C., Effect of Heat Treatment on Microstructure and Property of $\mathrm{Al}-\mathrm{Sn}-\mathrm{Pb}$ Bearing Material, J. Iron Steel Res. Int., 2006, 13, 2, 73-76.

[2]. Noskova N.I., Korshunov L.G., Korznikov A.V., Microstructure and tribological properties of Al - Sn, Al - Sn - Pb, AND Sn $\mathrm{Sb}-\mathrm{Cu}$ alloys subjected to severe plastic deformation, Met. Sci. Heat Treat., 2008, 50, 11-12, 593-599.

[3]. Noskova N.I., Vil'danova N.F., Filippov YuI., Churbaev R.V., Pereturina I.A., Korshunov L.G., Korznikov A.V., Preparation, deformation, and failure of functional $\mathrm{Al}-\mathrm{Sn}$ and $\mathrm{Al}-\mathrm{Sn}-\mathrm{Pb}$ nanocrystalline alloys, The Physics of Metals and Metallography, 2006, 102, 646-651.

[4]. Shim J.H., Lee H.N., Ha H.P., Cho Y.W., Yoon E.P., Liquid miscibility gap in the AlPb-Sn system, J. Alloys Compd., 2001, 327, 270-274.
[5]. Kittel C. Introduction to Solid State Physics, 8th Ed. John Wiley and Sons, New York, 2005, pp. 156.

[6]. Ari M., Saatçi B., Gündüz M., Meydaneri F., Bozoklu M., Microstructure and ThermoElectrical Transport Properties Of Cd-Sn Alloys, Mater. Charact., 2008, 59, 624-630.

[7]. Saatçi B., Ari M., Gündüz M., Türktekin S., Meydaneri F., Durmuş S., Özdemir M., Structural and Transport Properties Of Sn-Mg Alloys, Continuum Mech. Thermodyn., 2013, 25,739-748.

[8]. Ocak Y., Aksöz S., Maraşlı N., Keşlioğlu K., Thermal and electrical conductivity of $\mathrm{Sn}-$ Ag-In alloys, J. Non-Crystalline Solids., 2010, 356, 1795-1801.

[9]. Aksöz S., Maraşlı N., Thermal and And Electrical Conductivities Of Silver-IndiumTin Alloys, J. Physics Chem.Solids., 2012, 73, 902-910.

[10].Ari M., Saatçi B., Gündüz M., Payveren M., S. Durmuş, Thermo-Electrical Characterization of Sn-Zn Alloys, Mater. Charact., 2008, 59, 757-763.

[11].Saatci B., Ari M., Gündüz M., Meydaneri F., Bozoklu M., Durmus S., Thermal and Electrical Conductivities Of Cd-Zn Alloys, J. Phys. Condens. Matter., 2006, 18, 1064310653.

[12].Meydaneri F., Ari M., Saatçi B., ThermoElectrical Characterization Of Lead-Cadmium (Pb-Cd) Alloys, Accepted Manuscript, Int. J. Phys. Sci., 2012, 7, 48, 6210-6221.

[13].Cullity B.D.: Elements of X-Ray Diffraction, Inc, third edition, Addison-Wesley Publishing Company, United States of America, 1967.

[14].Callister W.D.: Materials Science and Engineering-An Introduction, John Wiley and Sons, New York, 1997.

[15].Smits F.M., Measurement the of Sheet Resistivities Four-Point Probe, The Bell sys. Tech. J., 1958, 711-718.

[16].Ziya A.B., Ohshima K., X-ray diffraction study of the structure and thermal parameters of the ternary $\mathrm{Au}-\mathrm{Ag}-\mathrm{Pd}$ alloys, J. Alloys Compd., 2006,425, 123-128. 
[17].Ju`sk'enas R., Mockus Z., Kanapeckaite S., Stalnionis G., Survila A., XRD studies of the phase composition of the electrodeposited copper-rich $\mathrm{Cu}-\mathrm{Sn}$ alloys, Electrochimica Acta. 2006, 52 , 928-935.

[18].Ortiz A.L., Shaw L., X-ray diffraction analysis of a severely plastically deformed aluminum alloy, Acta Mater., 2004, 52, 2185 2197.

[19].Shalaby R.M., Effect of silicon addition on mechanical and electrical properties of $\mathrm{Sn}-\mathrm{Zn}$ based alloys rapidly quenched from melt, Materials Science and Engineering A, 2012, 550, 112-117.

[20].Shalaby R.M., Effect of silver and indium addition on mechanical properties and indentation creep behavior of rapidly solidified Bi-Sn based lead-free solder alloys, Materials Science and Engineering A, 2013, 560, 86-95.

[21].Billah Md.M., Shorowordi K.M., Sharif A., Effect of micron size Ni particle addition in Sn-8Zn-3Bi lead-free solder alloy on the microstructure, thermal and mechanical propertiesJ. Alloys Compd., 2014, 585, 32-39.

[22].Scherrer P., Nachrichten von der Gesellschaft der Wissenschaften zu Göttingen, Mathematisch-Physikalische Klasse, Göttinger Nachrichten Gesell. (1918) 98-100.

[23].Patterson A.L., The Scherrer Formula for XRay Particle Size Determination, Phys. Rev., 1939, 56,978-982.

[24].Mishra R., Zemanova A., Kroupa A., Flandorfer H., Ipser H., Synthesis and characterization of Sn-rich $\mathrm{Ni}-\mathrm{Sb}-\mathrm{Sn}$ nanosolders, J. Alloys Compd., 2012, 513, 224-229.

[25].E. Çadırlı, U. Böyük, H. Kaya, N. Maraşlı, S. Aksöz, Y. Ocak, Dependence Of Electrical Resistivity On Temperature And Sn Content
In Pb-Sn Solders, J. Elect. Mater., 2011，40, 2,195-200.

[26].E. Çadırlı, H. Kaya, The effect of composition on microhardness and determination of electrical and thermal properties in the $\mathrm{Sn}-\mathrm{Cu}$ alloys, J. Mater. Sci : Materials In Electronics. 2011, 22, 1378-1386.

[27].Çadirli E., Böyük U., Kaya H., Maraşli N., Determination Of Mechanical, Electrical And Thermal Properties Of The Sn-Bi-Zn Ternary Alloy, J. Non-Crystalline Solids, 2011, 357, 2876-2881.

[28].Y. Ocak, S. Aksöz, N. Maraşli, K. Keşlioğlu, Dependency Of Thermal And Electrical Conductivity On Temperature And Composition Of Sn In Pb-Sn Alloys, Fluid Phase Equilibria, 2010, 295, 60-67.

[29].Öztürk E., Aksöz S., Keşlioğlu K., Maraşli N., The Measurement Of Thermal Conductivity Variation With Temperature For Sn-20 Wt.\% In Based Lead-Free Ternary Solders Thermochimica Acta, 2013, 554, 63-70.

[30].Kaygisiz Y., Ocak Y., Aksöz S., Keşlioğlu K., Maraşli N., Thermal Conductivity And Interfacial Energies Of Solid Sn3sb2 In The $\mathrm{Sn}-\mathrm{Sb}$ Peritectic System, Thermochimica Acta. 2011,520, 25-32.

[31].Saatçi B., Çimen S., Pamuk H., Gündüz M., The interfacial free energy of solid $\mathrm{Sn}$ on the boundary interface with liquid $\mathrm{Cd}-\mathrm{Sn}$ eutectic solution, J. Phys. Condens. Matter. 2007; 19: 326219 (11pp).

[32].Aksöz S., Ocak Y., Keşlioğlu K. Maraşl1 N., Determination Of Thermo-Electrical Properties In Sn Based Alloys, Met. Mater. Int. 2010, 16, 3, 507-515.

[33].Saatçi B., Maraşlı N., Gündüz M., Thermal Conductivities Of Solid And Liquid Phases In $\mathrm{Pb}-\mathrm{Cd}$ And Sn-Zn Binary Eutectic Alloys, Thermochimica Acta, 2007 ; 454 : 128-134. 